\begin{tabular}{|c|c|c|}
\hline $\begin{array}{l}\text { OPEN ACCESS } \\
\text { Vol. } 1 \text { No. 2: 13-23 } \\
\text { Tahun 2018 } \\
\text { Artikel penelitian 成 }\end{array}$ & $\begin{array}{l}\text { Jutracal Alsuatilklestari } \\
\text { E-ISSN: 2598-8204 } \\
\frac{\text { https://ojs.umrah.ac.id/index.php/akuatiklestari }}{\text { DOI : https://doi.org/10.31629/.v1i2.2289 }}\end{array}$ & $\stackrel{-}{0}$ \\
\hline
\end{tabular}

\title{
Potensi Ekologis dan Ekonomis Kerang Bulu (Anadara antiquata) di Desa Sebong Pereh Kabupaten Bintan
}

\author{
Ecological and Economic Potential of Shellfish (Anadara antiquata) in Sebong Pereh Village, \\ Bintan Regency
}

\section{Nurul Fitri ${ }^{1 凶}$, Fitria Ulfah ${ }^{2}$, Tri Apriadi ${ }^{1}$}

${ }^{1}$ Manajemen Sumberdaya Perairan, Fakultas Ilmu Kelautan dan Perikanan, Universitas Maritim Raja Ali Haji, Tanjungpinang, Indonesia 29111

2 Sosial Ekonomi Perikanan, Fakultas Ilmu Kelautan dan Perikanan, Universitas Maritim Raja Ali Haji, Tanjungpinang, Indonesia 29111

$\square$ Info Artikel:

Diterima: 30 April 2018

Revisi: 2 Mei 2018

Disetujui: 25 Mei 2018

Dipublikasi: 30 Mei 2018

Keyword:

CPUE, Potensi Ekologis, Ekonomis,

Kerang Bulu, Anadara antiquata

$\triangle$ Penulis Korespondensi:

Nurul Fitri

Manajemen Sumberdaya Perairan,

Fakultas Ilmu Kelautan dan Perikanan,

Universitas Maritim Raja Ali Haji,

Tanjungpinang, Indonesia 29111

Email: nurulfitri.msp@gmail.com

\begin{abstract}
ABSTRAK. Penelitian ini bertujuan untuk mengetahui potensi ekologis dan ekonomis kerang bulu (Anadara antiquata) dan potensi ekonomis pemanfaatan Kerang bulu (A. antiquata) di Desa Sebong Pereh Bintan. Penelitian ini dilakukan pada bulan Januari 2018. Metode yang digunakan untuk mengambil sampel kerang bulu adalah Random sampling sebanyak 30 titik diperairan Desa Sebong Pereh Bintan. Teknik wawancara yang digunakan adalah Snowball sampling (bola salju), dimana responden yang dibutuhkan untuk peneliti pemula adalah minimal 30 orang. Pemanfaatan ekonomis Kerang bulu ( . antiquata) menggunakan rumus CPUE dan menghitung nilai manfaat langsung Kerang bulu ( $A$. antiquata) di desa Sebong Pereh Bintan. Hasil penelitian menunjukkan rata-rata kelimpahan Kerang bulu (A. antiquata) di desa Sebong Pereh berkisar 5700 ind/ha dan kelimpahan Kerang bulu (A. antiquata) di desa Sebong Pereh Bintan tergolong sedang. Kondisi perairan di desa Sebong Pereh masih memenuhi baku mutu sehingga mendukung kehidupan Kerang bulu ( $A$. antiquata). Total rata-rata hasil tangkapan berkisar 509,75 kg/minggu dengan rata-rata $51 \mathrm{trip/minggu.} \mathrm{Pendapatan} \mathrm{rata-rata}$ nelayan Kerang bulu ( $A$. antiquata) berkisar Rp. 339.833,-/bulan atau jika diakumulasikan berkisar Rp. 4.078.000,-/tahun. Penelitian lanjutan diperlukan terkait dengan analisis pertumbuhan Kerang bulu dengan data panjang berat, kajian stok kerang bulu (A. antiquata), dan pemanfaatan Kerang bulu ( $A$. antiquata) pada saat musim teduh.
\end{abstract}

ABSTRACT. The purpose of this research is to find out the ecological and economic potential of Shellfish (Anadara antiquata) and the economical utilization of Shellfish (A. antiquata) in Sebong Pereh Village, Bintan Regency. This research was conducted on January 2018. The researcher used the Random Sampling method on 30 water points in Sebong Pereh Village, Bintan Regency. The interview technique was Snowball Sampling with 30 respondents which were needed by the beginner researcher. The economical utilization of Shellfish (A. antiquata) used CPUE formula to count the utilization value of Shellfish (A. antiquata) in Sebong Pereh Village, Bintan Regency. The result of this research shows that the abundance mean of Shellfish (A. antiquata) is 5700 ind/ha and the abundance category is moderate. The water category in Sebong Pereh Village, Bintan Regency was on standardizing condition thus the existence of Shellfish ( $A$. antiquata) has been supported. The mean value of catching result of Shellfish (A. antiquata) was around 509,75 kg/week and 51 trips/week. The mean value of the Shellfish (A. antiquata) fishermen' income was around Rp. 339.833,-/month or Rp. 4.078.000,/year. The intermediate research was needed to find out deeply about the analysis of the Shellfish's growth with the weight length data, the analysis of Shellfish's stock and its utilization on the calm season.

首 How to cite this article:

Fitri, N., Ulfah, F., \& Apriadi, T. (2018). Potensi Ekologis dan Ekonomis Kerang Bulu (Anadara antiquata) di Desa Sebong Pereh Kabupaten Bintan. Jurnal Akuatiklestari. 1(2): 13-23. https://doi.org/10.31629/.v1i2.2289

\section{PENDAHULUAN}

Desa Sebong Pereh merupakan salah satu desa di Kecamatan Teluk Sebong Kabupaten Bintan. Secara ekologis Desa Sebong Pereh memiliki potensi sumber daya laut cukup tinggi yang dapat memberikan nilai komersial terhadap masyarakat nelayan lokal dan sebagian besar berprofesi sebagai nelayan yang menggantungkan kebutuhan hidupnya 
pada sumberdaya perikanan kelautan. Salah satu sumberdaya yang banyak ditangkap oleh masyarakat Desa Sebong Pereh adalah jenis kerang-kerangan, salah satunya adalah kerang bulu (Anadara antiquata). Kerang bulu (A. antiquata) merupakan hewan dari filum moluska dan kelas bivalvia.

Kerang bulu merupakan hasil laut yang ditangkap masyarakat karena mempunyai nilai gizi yang cukup tinggi meliputi protein, asam amino, asam lemak, vitamin dan mineral. Selain menjadi kebutuhan bagi masyarakat, penangkapan kerang bulu di Desa Sebong Pereh juga untuk memenuhi permintaan pasar antara lain hotel, restoran seafood dan pasar ekspor, sehingga permintaannya pun cenderung meningkat. Meningkatnya permintaan tersebut, secara tidak langsung akan berdampak terhadap meningkatnya upaya penangkapan kerang bulu di alam.

Penangkapan yang berlebihan akan mengakibatkan penurunan populasi kerang bulu. Pemanfaatan kerang A. antiquata oleh masyarakat secara terus menerus mengakibatkan penurunan jumlah populasi serta mengganggu pertumbuhan populasi. Kegiatan pemanfaatan secara tidak terkontrol tersebut akan berdampak terhadap kerang A. antiquata yang meliputi; (1) ukuran hasil tangkapan yang makin kecil; (2) bobot setiap kerang rendah; dan, (3) jumlah hasil tangkapan yang menurun (Setiawan et al., 2016).

Penangkapan yang tidak dikelola akan menyebabkan terjadinya penurunan jumlah serta mengganggu pertumbuhan populasi kerang bulu. Penurunan hasil tangkapan akan berbanding lurus pada penurunan komposisi jenis dan keberagaman kerang bulu dalam hal ini (A. antiquata) di Desa Sebong Pereh. Oleh karena itu perlu dilakukan penelitian mengenai potensi ekologis dan ekonomis kerang bulu (A. antiquata) sebagai bahan informasi yang lengkap terkait dengan keberadaan kerang bulu (A. antiquata) di Desa Sebong Pereh Kecamatan Teluk Sebong Kabupaten Bintan.

\section{BAHAN DAN METODE}

\subsection{Waktu dan Tempat}

Penelitian ini dilaksanakan pada bulan Januari 2018 di Perairan Desa Sebong Pereh Kecamatan Teluk Sebong Kabupaten Bintan. Pengukuran substrat dilakukan di Laboratorium Biologi Laut, Fakultas Ilmu Kelautan dan Perikanan, Universitas Maritim Raja Ali Haji. Peta lokasi penelitian dapat dilihat pada Gambar 1.

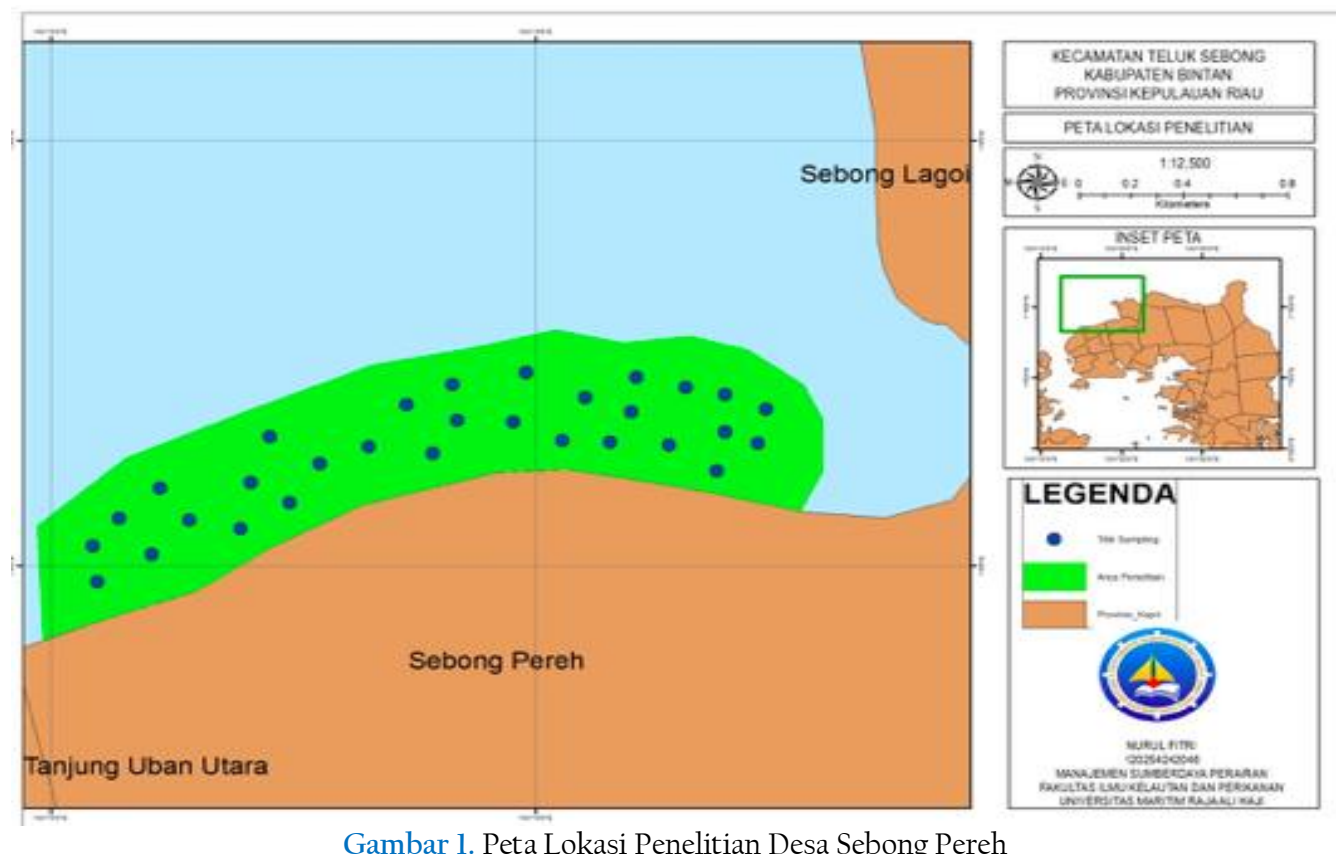

\subsection{Alat dan Bahan}

Alat dan bahan yang digunakan dalam penelitian ini diantaranya plot $1 \mathrm{xl} \mathrm{m}$ adalah untuk pengambilan sampel kerang bulu (A. antiquata) di setiap titik samplingnya. GPS digunakan untuk menentukan titik koordinat lokasi penelitian, plastik sampel diperlukan untuk mengambil sampel kerang bulu, kamera digital digunakan untuk dokumentasi penelitian. Multi tester berfungsi untuk mengukur parameter seperti $\mathrm{pH}$, suhu, dan DO perairan di lokasi penelitian. Refraktometer digunakan untuk mengukur salinitas, pelampung arus berfungsi untuk mengukur kecepatan arus dan sekop untuk pengambilan substrat di lokasi penelitian Desa Sebong Pereh.

\subsection{Prosedur Penelitian}

\subsubsection{Penentuan Titik Sampling}

Penelitian dilakukan pada Perairan Desa Sebong Pereh Kecamatan Teluk Sebong Kabupaten Bintan. Penentuan titik sampling menggunakan metode random sampling sebanyak 30 titik pada ekosistem padang lamun. 


\subsubsection{Penentuan Responden}

Responden dalam p enelitian ini adalah nelayan yang menangkap Kerang Bulu di Desa Sebong Pereh Kecamatan Teluk Sebong Kabupaten Bintan. Metode yang digunakan adalah metode deskriptif dengan teknik survei dan wawancara semi struktural. Teknik survei merupakan teknik penelitian yang mengambil sampel dari suatu populasi dengan menggunakan kuisioner sebagai alat pengumpulan data yang pokok dan wawancara semi stuktural merupakan teknik pengumpulan data dengan melakukan interaksi dan komunikasi yang tidak mengacu sepenuhnya pada daftar pertanyaan. Tujuan wawancara jenis ini adalah untuk menemukan permasalahan secara lebih terbuka dan pihak yang diajak wawancara diminta pendapatnya.

Wawancara dilakukan pada semua nelayan yang mengambil kerang bulu dan pengumpul kerang bulu yang terdapat di Desa Sebong Pereh. Pada penelitian ini, jumlah populasi nelayan diketahui sebanyak 157 orang, namun tidak terkhusus nelayan yang hanya menangkap kerang bulu saja. Dari 157 orang nelayan desa Sebong Pereh akan diambil 30 orang yang dijadikan sebagai sampel yaitu nelayan dan wanita nelayan yang menangkap kerang, jumlah ini diambil karena peneliti adalah peneliti pemula, maka angka 30 merupakan perkiraan peneliti yang diyakini dapat menjadi data pendukung di lokasi penelitian. Sedangkan teknik penentuan sampel menggunakan teknik snowball sampling (bola salju).

Teknik sampling snowball adalah suatu teknik yang multitahapan, didasarkan pada analogi bola salju, yang dimulai dengan bola salju yang kecil kemudian membesar secara bertahap karena ada penambahan salju ketika digulingkan dalam hamparan salju. Ini dimulai dengan beberapa orang atau kasus, kemudian meluas berdasarkan hubunganhubungan terhadap responden. Responden sebagai sampel yang mewakili populasi, kadang tidak mudah didapatkan langsung di lapangan. Untuk dapat menemukan sampel yang sulit diakses, atau untuk memperoleh informasi dari responden mengenai permasalahan yang spesifik atau tidak jelas terlihat di dunia nyata, maka teknik sampling snowball merupakan salah satu cara yang dapat diandalkan dan sangat bermanfaat dalam menemukan responden yang dimaksud sebagai sasaran penelitian melalui keterkaitan hubungan dalam suatu jaringan, sehingga tercapai jumlah sampel yang dibutuhkan. Dalam sampling snowball, identifikasi awal dimulai dari seseorang atau kasus yang masuk dalam kriteria penelitian (Nurdiani, 2014).

\subsection{Teknik Pengumpulan Data}

Data primer pada penelitian ini adalah kepadatan kerang bulu dan parameter lingkungan seperti substrat serta pemanfaatan kerang bulu yang didapatkan dari wawancara kepada nelayan dan pengumpul di Desa Sebong Pereh.

Data sekunder pada penelitian ini adalah kondisi umum Desa Sebong Pereh yang didapatkan dari instansi pemerintah. Identifikasi jenis Kerang Bulu mengacu pada website WoRMS (World Register of Marine Species) dan buku identifikasi bivalvia, serta baku mutu perairan yang mengacu pada Kepmen LH No. 5l Tahun 2004.

\subsection{Analisis Data}

Data yang telah didapat disajikan dalam bentuk analisis deskriptif kualitatif dengan cara tabulasi dan digambarkan secara grafik. Keberadaan kerang bulu di alam dan kerang bulu yang ditangkap akan dikonversi perminggu dan akan didapatkan persen rata-rata kerang bulu yang ditangkap oleh nelayan Desa Sebong Pereh, kemudian data yang didapat akan dianalisis secara deskriptif sehingga dapat diperoleh gambaran bagaimana potensi ekologis dan ekonomis Kerang bulu di Desa Sebong Pereh.

\subsubsection{Kelimpahan Kerang Bulu}

Kelimpahan adalah banyaknya jumlah individu dan jumlah jenis yang ditemukan pada luas daerah pengamatan. Kelimpahan kerang bulu dapat dihitung dengan menggunakan rumus (Prasojo et al., 2012):

$$
A=\frac{X}{n}
$$

Keterangan :

$\mathrm{A}=$ Kelimpahan/kepadatan $\left(\mathrm{Ind} / \mathrm{m}^{2}\right)$

$\mathrm{X}=$ Jumlah Individu (Ind)

$\mathrm{n}=$ Luas Area $\left(\mathrm{m}^{2}\right)$

\subsubsection{CPUE}

Perhitungan nilai hasil tangkapan per satuan upaya penangkapan (Catch per Unit Effort) diperoleh dengan membagi data hasil tangkapan dengan upaya penangkapan. Upaya penangkapan dapat berupa trip penangkapan, jumlah armada yang melakukan operasi penangkapan, atau jumlah alat tangkap. Menurut Sparre dan Venema (1999) rumus yang digunakan untuk mengetahui nilai hasil tangkapan per satuan upaya penangkapan (CPUE) adalah sebagai berikut :

$$
\text { CPUE } i=\frac{\text { Catch } i}{\text { Effort } i}
$$

Keterangan :

CPUE $_{\mathrm{i}} \quad$ = hasil tangkapan per satuan upaya penangkapan dalam tahun ke $\mathrm{i}$ 
Catch $_{\mathrm{i}} \quad=$ hasil tangkapan dalam tahun ke-i

Effort $_{\mathrm{i}} \quad=$ Upaya penangkapan dalam tahun ke-i

Namun, setelah dilakukan pencarian data di Dinas Kelautan dan Perikanan Kabupaten Bintan dan Dinas Kelautan dan Perikanan Provinsi Kepulauan Riau, tidak ditemukannya data time series untuk penangkapan Kerang Bulu selama 5 tahun terakhir. Oleh karena itu peneliti mencoba memodifikasi rumus dimana hasil tangkapan dan upaya penangkapan dalam tahun ke-i dirubah menjadi minggu ke-i, dengan rumus sebagai berikut :

$$
\text { CPUE } i=\frac{\text { Catch } i}{\text { Effort } i}
$$

Keterangan :

$\mathrm{CPUE}_{\mathrm{i}} \quad=$ hasil tangkapan per satuan upaya penangkapan dalam minggu ke $\mathrm{i}$

Catch $_{i} \quad=$ hasil tangkapan dalam minggu ke-i

Effort $_{\mathrm{i}} \quad$ = Upaya penangkapan dalam minggu ke- $\mathrm{i}$

\subsubsection{Nilai Manfaat Langsung (Direct Use Value)}

Nilai manfaat langsung adalah nilai yang dihasilkan dari pemanfaatan langsung suatu sumberdaya, yang dapat diartikan juga sebagai manfaat yang dapat dikonsumsi atau dinikmati sehingga dapat dirasakan manfaatnya secara langsung, sehingga dapat dihitung dengan bersamaan sebagai berikut (Suzana et al. 2011 in Agustina, 2014) :

$$
D U V=\sum_{i}^{n}(D U V i)
$$

Keterangan :

DUV = Direct use value (Nilai manfaat langsung)

DUVi $=$ Manfaat penangkapan Kerang Bulu (harga kerang bulu/kg)

$\mathrm{n} \quad=$ Jumlah jenis pemanfaatan

i $\quad=$ Jenis pemanfaatan ke-i

Nilai manfaat langsung digunakan untuk mengetahui harga kerang bulu, jumlah tangkapan kerang bulu per harinya dan untuk mengetahui pendapatan rata-rata nelayan kerang bulu di Desa Sebong Pereh.

\section{HASIL DAN PEMBAHASAN}

\subsection{Kelimpahan Kerang Bulu}

Kelimpahan kerang bulu merupakan jumlah kerang bulu yang dijumpai dibagi dengan luasan area pengamatan. Kelimpahan kerang bulu disajikan dengan satuan individu per meter persegi $\left(\mathrm{ind} / \mathrm{m}^{2}\right)$. Hasil perhitungan kelimpahan kerang bulu di Perairan Sebong Pereh disajikan pada Gambar 2.



Gambar 2. Kelimpahan kerang bulu di Perairan Sebong Pereh

Kelimpahan kerang bulu di perairan Desa Sebong Pereh berkisar antara 1-3 ind $/ \mathrm{m}^{2}$, dengan rata-rata kelimpahan yakni $0,57 \mathrm{ind} / \mathrm{m}^{2}$ (5700 ind/hektar). Jika dibandingkan dengan penelitian Riniatsih dan Widianingsih (2007), jenis kerang bulu A. ferruginea memiliki kelimpahan sebesar 2,25 ind $/ \mathrm{m}^{2}$. Kemudian mengacu pada penelitian Prasojo et al. (2012), bahwa kelimpahan kerang A. granosa memiliki kisaran antara 0,13-0,23 ind $/ \mathrm{m}^{2}$. Hasil penelitian Satrioajie (2012), memperoleh kelimpahan kerang bulu A.pilula berkisar antara 0,03-0,86 ind $/ \mathrm{m}^{2}$. Penelitian Dayanti et al. (2017) kelimpahan 
kerang bulu berkisar antara 0,40-0,94 ind $/ \mathrm{m}^{2}$. Jika mengacu dari beberapa referensi diatas, hasil kelimpahan A. antiquata di perairan Sebong Pereh tergolong kelimpahan yang sedang. Beberapa hasil penelitian menunjukkan kelimpahan yang lebih rendah, namun beberapa penelitian lainnya menunjukkan nilai kelimpahan yang lebih tinggi. Kelimpahan Kerang Bulu A. antiquata yang tidak tergolong tinggi di perairan Desa Sebong Pereh selain disebabkan oleh faktor substrat, juga dipengaruhi oleh adanya upaya penangkapan yang terus dilakukan sehingga akan mempengaruhi populasinya di alam.

Jenis substrat yang telah diidentifikasi oleh peneliti yakni bertekstur pasir, sedangkan beberapa spesies bivalvia lebih menyukai jenis substrat yang lebih halus (pasir berlumpur ataupun lumpur berpasir). Seperti pernyataan Riniatsih dan Kushartono (2009), pada tekstur substrat dasar lumpur berpasir memiliki kandungan bahan organik yang tinggi dibandingkan tekstur substrat dasar pasir karena semakin halus tekstur substrat dasar maka kemampuan dalam menjebak bahan organik akan semakin besar. Menurut Kharisma et al. (2012), perairan dengan sedimen yang kasar memiliki kandungan bahan organik rendah karena partikel yang lebih halus tidak dapat mengendap. Selain karena kandungan bahan organik yang rendah dan kondisi substrat dasar yang tidak sesuai dengan habitat bivalvia termasuk jenis A. antiquata.

Sedimen yang halus memiliki kandungan unsur hara yang lebih tinggi dibandingkan dengan substrat kasar. Seperti pernyataan Putri et al. (2016), sedimen atau substrat dasar yang terus menerus menumpuk serta adanya bawaan nutrien dari mahluk hidup maupun limbah akan membentuk kandungan bahan organik. Berdasarkan penelitiannya total kandungan bahan organik tertinggi terdapat pada tekstur lempung berdebu dibandingkan pada tekstur pasir. Bahan organik yang terdapat pada sedimen atau substrat dimanfaatkan oleh hewan bentos salah satunya kerang bulu untuk bahan makanan dengan cara filter feeder (cara makan dengan menyaring substrat).

Menurut Riniatsih dan Widianingsih (2007), secara umum kelas bivalvia termasuk kerang-kerangan melimpah pada jenis substrat pasir berlumpur karena berkaitan dengan persediaan makanan yang berlimpah. Selanjutnya, Ernawati et al. (2015), menyatakan bahwa kerang laut termasuk kerang bulu dimanfaatkan sebagai sumber bahan makanan oleh masyarakat Indonesia, terutama bagi yang hidup di sekitar pesisir perairan pantai. Untuk itu, eksploitasi terhadap jenis kerang bulu terus dilakukan untuk memenuhi kebutuhan masyarakat. Upaya eksploitasi yang terus meningkat tentunya akan berdampak pada penurunan populasi kerang bulu termasuk kelimpahannya.

\subsection{Pemanfaatan Kerang Bulu}

Pemanfaatan kerang bulu yang meliputi hasil tangkapan, upaya tangkapan, serta hasil per upaya penangkapan (CPUE) di perairan Desa Sebong Pereh dilakukan dengan waktu pengamatan selama 1 bulan dengan ulangan sampling per minggu (selama 4 minggu). Hasil tangkapan, upaya tangkapan, serta hasil per upaya penangkapan (CPUE) kerang bulu A. antiquata di perairan Desa Sebong Pereh disajikan pada Gambar 3.

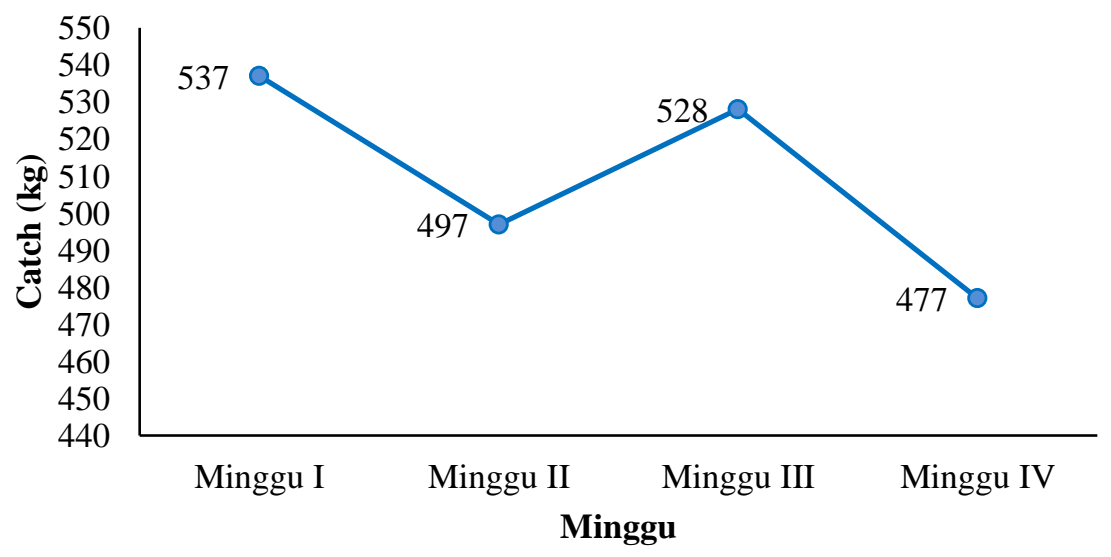

(a)

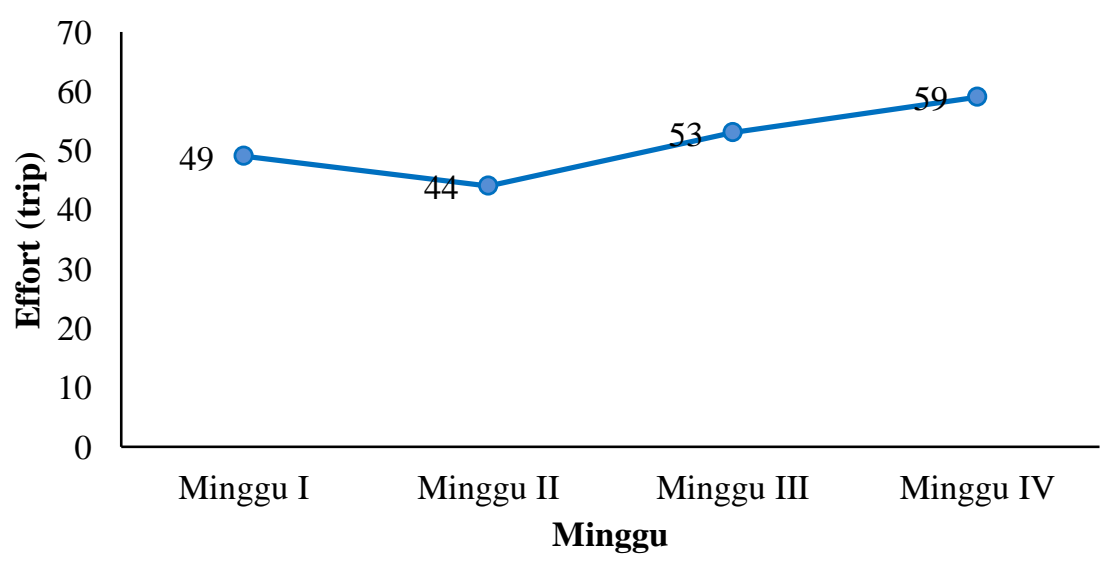

(b) 


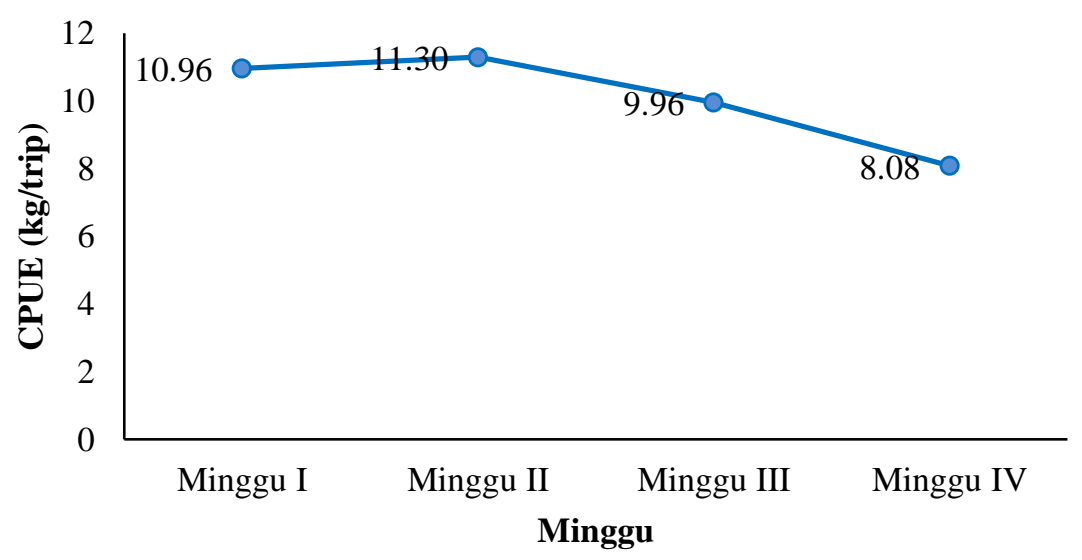

(c)

Gambar 3. (a) Hasil tangkapan, (b) upaya tangkapan, serta (c) hasil per upaya penangkapan (CPUE) di Perairan Desa Sebong Pereh

Hasil tangkapan kerang bulu yang dilakukan oleh nelayan di perairan Sebong Pereh mengalami fluktuasi dari minggu ke minggu. Total hasil tangkapan (catch) yang diperoleh berkisar antara 477-537 kg/minggu dengan hasil tangkapan rata-rata sebesar 509,75 kg/minggu. Pada minggu I, hasil tangkapan kerang bulu paling tinggi dibandingkan dengan minggu-minggu lainnya. Menurut masyarakat nelaya kerang bulu, pada saat minggu I terjadi optimalisasi pasang surut dimana kondisi surut airnya lebih lama dan penangkapan kerang bulu dapat dilakukan lebih lama (dapat mencapai 4 jam). Hasil tangkapan kerang bulu tersebut masih tergolong rendah. Rendahnya hasil tangkapan kerang bulu di Desa Sebong Pereh disebabkan oleh kondisi perairan yakni salinitas yang tidak sesuai dengan baku mutu. Hasil pengukuran salinitas, menunjukkan nilai dibawah baku mutu sehingga mempengaruhi hasil tangkapan kerang bulu. Kemudian, pada saat pengambilan data dilakukan pada bulan Januari yang masih tergolong kedalam musim peralihan. Pada musim peralihan ini hasil tangkapan kerang bulu umumnya lebih rendah.

Diketahui dari hasil wawancara kepada masyarakat yang menangkap kerang bulu Desa Sebong Pereh, cara penangkapan yang digunakan masih tradisional yakni langsung menggunakan tangan, sehingga hasil tangkapan lebih rendah dibandingkan dengan menggunakan alat tangkap. Akan tetapi, penggunaan alat tangkap akan merusak ekosistem perairan dan menyebabkan penangkapan kerang bulu akan lebih tinggi. Hal ini akan berdampak pada penurunan populasinya. Cara penangkapan yang dilakukan oleh masyarakat Desa Sebong Pereh tanpa menggunakan alat cukup membantu dalam menjaga kerusakan ekosistem dan menjaga populasi kerang bulu. Meskipun hasil tangkapan (catch) yang diperoleh lebih kecil, akan tetapi dapat terus berlanjut pada masa yang akan datang.

Hasil tangkapan (catch) kerang bulu di Desa Sebong Pereh yang tidak terlalu tinggi juga disebabkan oleh area tangkapan yang terbatas. Dari hasil penelitian, diperolah informasi bahwa penangkapan kerang bulu hanya dilakukan pada kawasan pasang-surut (intertidal zone) pada jarak antara 30-200 m dari bibir pantai ke arah laut. Waktu penangkapan yang dilakukan oleh nelayan juga terbatas, hanya dilakukan pada saat air surut. Penangkapan tidak dilakukan pada saat air laut pasang dengan cara penyelaman sehingga hasil tangkapan kerang bulu (catch) masih tergolong rendah.

Hasil perhitungan upaya penangkapan (dalam trip) terhadap penangkapan kerang bulu di Sebong Pereh, nilai upaya penangkapannya fluktuatif antara 44-59 trip/minggu dengan rata-rata upaya sebesar 51 trip/minggu. Pada grafik, terlihat bahwa upaya penangkapan tertinggi pada minggu IV dengan nilai sebesar 59 trip. Terlihat bahwa peningkatan upaya tangkapan (effort) tidak sepenuhnya berbanding lurus dengan hasil tangkapan kerang bulu. Seperti hasil penelitian bahwa jumlah upaya sebesar 59 trip/minggu hanya menghasilkan sebesar $477 \mathrm{~kg} /$ minggu, sedangkan jumlah upaya yang lebih kecil yakni 49 trip/minggu justru mampu menghasilkan sebesar $537 \mathrm{~kg} /$ minggu. Hasil tangkapan, tidak hanya dipengaruhi oleh jumlah upaya melainkan terdapat faktor lain yakni cuaca dan kondisi lingkungan. Menurut Susilo et al. (2015) Hasil tangkapan sumberdaya perikanan berfluktuasi seiring dengan perubahan musim. Musim panen umumnya terjadi pada musim peralihan timur menuju ke barat, pada bulan November akan mengalami penurunan, sedangkan pada musim barat hingga peralihan menuju timur nilai produksi mencapai nilai tertinggi, serta pada bulan Desember merupakan hasil tangkapan terendah karena cuaca yang kurang baik.

Menurut Wiyono (2009), umumnya masyarakat nelayan akan cenderung meningkatkan upaya penangkapan atas sumberdaya perairan meskipun membutuhkan biaya yang cukup tinggi. Dengan biaya operasi penangkapan yang semakin meningkat sementara hasil tangkapan semakin menurun, mendorong nelayan untuk melakukan proses penangkapan guna mendapatkan hasil tangkapan sebanyak-banyaknya untuk mengimbangi biaya operasi penangkapan yang semakin tinggi (Susiana \& Rochmady, 2018). Jika kondisi ini terus terjadi maka berpeluang besar terjadinya over eksploitasi dan penurunan populasi. Sesuai dengan hasil penangkapan kerang bulu di Desa Sebong Pereh bahwa memaksimalkan upaya tangkapan tidak berkorelasi positif dengan peningkatan hasil tangkapan. 
Dari grafik CPUE terlihat bahwa optimalisasi penangkapan kerang bulu terdapat pada minggu II dengan nilai 11,3 $\mathrm{kg} /$ trip, sedangkan pada minggu IV memperoleh nilai CPUE terendah hanya $8,08 \mathrm{~kg} /$ trip. Fluktuasi CPUE tejadi karena adanya fluktuasi upaya (effort) dan hasil tangkapan (catch) pada minggu ke minggu. Faktor cuaca dan kondisi lingkungan menjadi faktor yang mempengaruhi fluktuasi CPUE.

Nilai CPUE cenderung menurun pada minggu ke IV meskipun nilai upaya yang dilakukan ditingkatkan menggambarkan terjadinya optimalisasi penangkapan kerang bulu. Artinya jika terus dilakukan peningkatan upaya tangkapan justru akan memperoleh hasil yang menurun dan mengarah kepada tangkapan lebih. Menurut Susiana \& Rochmady (2018), kondisi yang mencirikan telah terjadi tangkapan lebih yakni waktu penangkapan lebih panjang, lokasi penangkapan cenderung lebih jauh, produktivitas/ laju tangkap (CPUE) cenderung menurun, ukuran ikan sasaran semakin kecil, dan biaya operasi penangkapan semakin meningkat.

\subsection{Nilai Manfaat Langsung}

Direct Use Value (DUV) atau nilai manfaat langsung dari hasil penangkapan kerang bulu yang dinilai dalam rupiah (Rp.). Hasil perhitungan nilai manfaat langsung atau Direct Use Value (DUV) penangkapan kerang bulu di perairan Sebong Pereh berkisar antara Rp. 79.500,- perminggu hingga Rp. 89.500,- perminggu dengan rata-rata nilai manfaat langsung sebesar Rp. 84.958,- perminggu. Dengan demikian, pendapatan nelayan kerang bulu berkisar antara Rp. 318.000,- perbulan hingga Rp. 358.000,- perbulan dengan rata-rata Rp. 339.833,- perbulan (Rp. 4.078.000,- pertahun). Nilai manfaat langsung dari penangkapan kerang bulu cukup membantu nelayan sebagai penghasilan tambahan untuk menunjang kehidupannya sehari-hari. Diketahui kerang bulu dijual dengan harga Rp. 5.000,- per kg beserta cangkang dan Rp. 40.000,- per kg untuk kerang bulu yang telah dilepaskan dari cangkangnya. Akan tetapi, seluruh nelayan menjual kerang bulu beserta dengan cangkangnya.

Berdasarkan hasil pengamatan peneliti, bahwa dalam 1 kg kerang bulu dengan cangkang hanya akan menghasilkan kerang bulu bersih (tanpa cangkang) seberat 180 gram. Dengan demikian, untuk menghasilkan 1 kg kerang bulu bersih (tanpa cangkang) membutuhkan kerang bulu bercangkang sebanyak $\pm 6 \mathrm{~kg}$. Keuntungan yang diperoleh oleh masyarakat hanya sebesar Rp. 10.000 jika dibandingkan dengan menjual kerang bulu dengan cangkang. Keuntungan sebesar Rp. 10.000 diangap kurang sesuai dengan upah merebus kerang bulu serta upah untuk membersikannya, sehingga keseluruhan responden menjual kerang bulu tersebut beserta dengan cangkangnya.

Nilai manfaat langsung merupakan bentuk manfaat yang diperoleh oleh masyarakat dari kegiatan eksploitasi terhadap sumberdaya yang menghasilkan nilai langsung dalam bentuk uang. Menurut Supriadi (2002), dalam penilaian ekonomi sumberdaya laut, umumnya ditransormasikan dalam bentuk uang dengan cara: a) mengidentifikasi fungsi dan manfaat sumberdaya laut tersebut, b) menghitung manfaat dan fungsi sumberdaya laut kedalam nilai uang, dan c) menilai total keuntungan bersih dari seluruh fungsi dan manfaat dari sumberdaya laut yang dimanfaatkan tersebut. Dalam penilaiannya dikenal dengan manfaat langsung (Direct use value), manfat tidak langsung (Indirect use value), manfaat tambahan (Optional value).

Namun dalam kenyataannya, pemanfaatan sumberdaya laut secara Direct use value memberikan dampak ekonomi secara lanngsung kepada masyarakat. Nilai tersebut dapat digunakan sebagai penunjang kehidupan dan penambah penghasilan bagi masyarakat. Nilai uang yang diperoleh dari hasil pemanfaatan sumberdaya laut, dapat ditukarkan dengan kebutuhan masyarakat untuk kehidupannya sehari-hari (Rochmady \& Susiana, 2014). Termasuk sumberdaya kerang bulu di Sebong Pereh yang memiliki fungsi secara ekonomis bagi pendapatan masyarakat sekitar Sebong Pereh.

\subsection{Karakteristik Nelayan Kerang Bulu di Desa Sebong Pereh}

Karakteristik nelayan yang melakukan penangkapan kerang bulu di Perairan Desa Sebong Pereh yang meliputi jenis kelamin, pendidikan, umur, pekerjaan, serta jenis pekerjaan penangkapan kerang bulu. Jumlah nelayan kerang bulu berdasarkan jenis kelamin yang melakukan penangkapan di Perairan Desa Sebong Pereh disajikan secara jelas seperti pada Gambar 4.

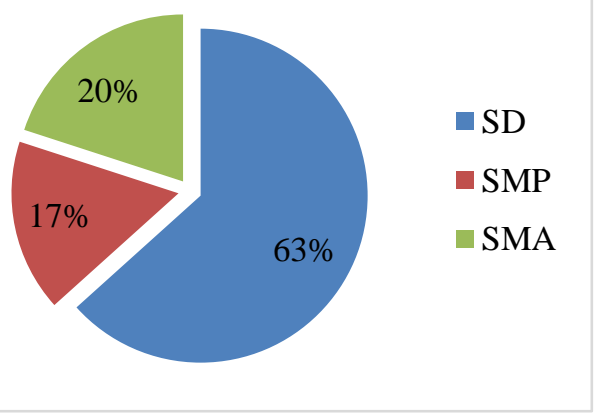

(a)

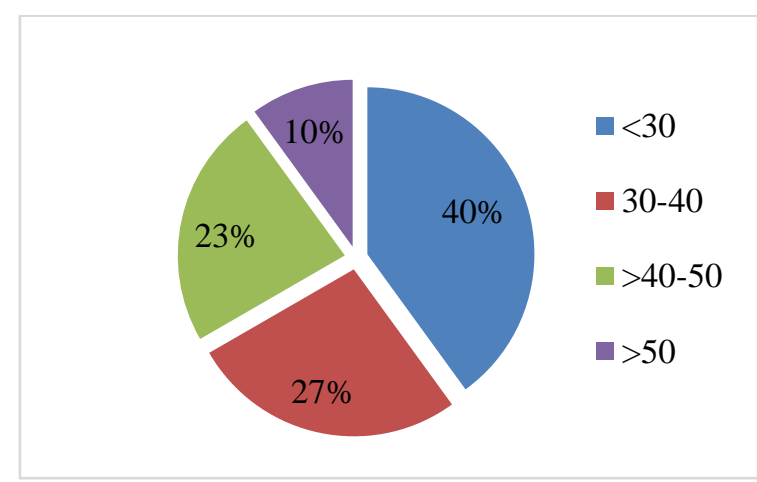

(b) 


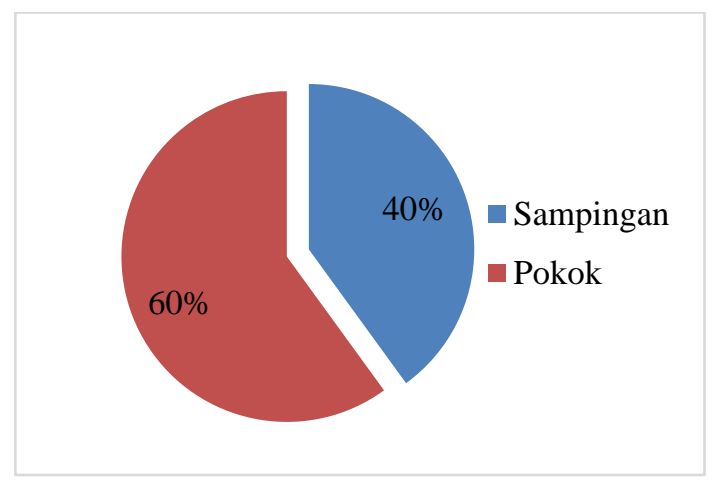

(c)

Gambar 4. Karakteristik Nelayan kerang bulu di Desa Sebong Pereh berdasarkan : (a) pendidikan, (b) umur, (c) pekerjaan

Berdasarkan hasil wawancara kepada nelayan yang melakukan penangkapan kerang bulu di Desa Sebong Pereh $70 \%$ dari total 30 orang nelayan berjenis kelamin laki-laki, sedangkan sisanya 30\% adalah perempuan. Dari data yang diperoleh, nelayan laki-laki lebih dominan dengan jarak tangkapan yang lebih jauh hingga batas tubir dibandingkan dengan nelayan perempuan yang melakukan tangkapan kerang bulu hanya pada area litoral pasang surut.

Karakteristik nelayan yang melakukan penangkapan kerang bulu juga beragam dari segi umur. Namun dari hasil wawancara, nelayan dengan umur $>30$ tahun merupakan yang paling dominan dengan persentase $40 \%$. Selanjutnya diikuti oleh nelayan dengan umur $\mathbf{3 0}$-40 tahun dengan persentase 27\%, dan nelayan kerang bulu dengan umur antara $>40-50$ dengan persentase sebesar 23\%, serta nelayan dengan umur $>50$ tahun yakni sebesar $10 \%$. Umumnya nelayan kerang bulu dominan pada umur produktif yang masih memiliki tenaga lebih untuk melakukan penangkapan kerang bulu sebagai penghasilan tambahan.

Persentase nelayan kerang bulu berdasarkan pendidikan didominasi oleh nelayan dengan lulusan Sekolah Dasar (SD) dengan persentase mencapai 63\%, sedangkan nelayan kerang bulu yang berpendidikan Sekolah Menengah Pertama (SMP) sebesar 17\% dan sisanya sebesar 20\% merupakan nelayan penangkap kerang bulu dengan pendidikan Sekolah Menengah Atas (SMA). Beberapa diantara para nelayan kerang bulu, masih menempuh pendidikan di Sekolah Menengah Atas (SMA) sehingga statusnya masih pelajar. Penangkapan kerang bulu dijadikan sebagai pekerjaan untuk membantu uang sekolah dan digunakan untuk keperluan sehari-hari.

Aktivitas penangkapan kerang bulu digolongkan atas 2 kelompok yakni sebagai pekerjaan pokok ataupun hanya sebagai pekerjaan sampingan. Berdasarkan hasil wawancara kepada nelayan kerang bulu, sebesar $40 \%$ nelayan menjadikan penangkapan kerang bulu sebagai pekerjaan sampingan. Sedangkan $60 \%$ responden lainnya menjadikan pekerjaan penangkapan kerang bulu menjadi pekerjaan pokok. Kondisi ini menggambarkan bahwa sumberdaya kerang bulu merupakan salah satu sumber penghasilan utama nelayan, namun kondisi tersebut menyebabkan ekploitasi kerang bulu akan terus berlanjut.

\subsection{Kondisi Penangkapan Kerang Bulu}

Hasil wawancara terkait dengan pemanfaatan kerang bulu terkait dengan alasan penangkapan, cara penangkapan, musim penangkapan, waktu penangkapan, lama waktu penangkapan, ukuran kerang bulu yang ditangkap, jarak penangkapan, dan distribusi penjualan. Untuk alasan penangkapan dan cara penangkapan kerang bulu secara jelas disajikan seperti Gambar 5.

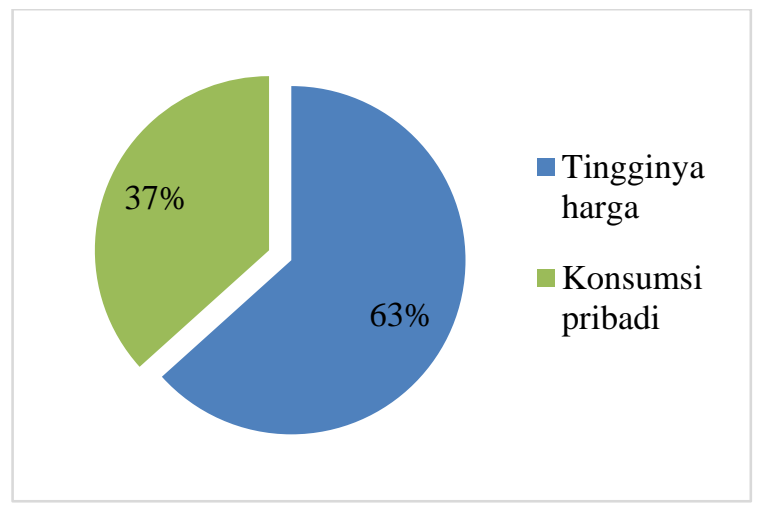

(a)

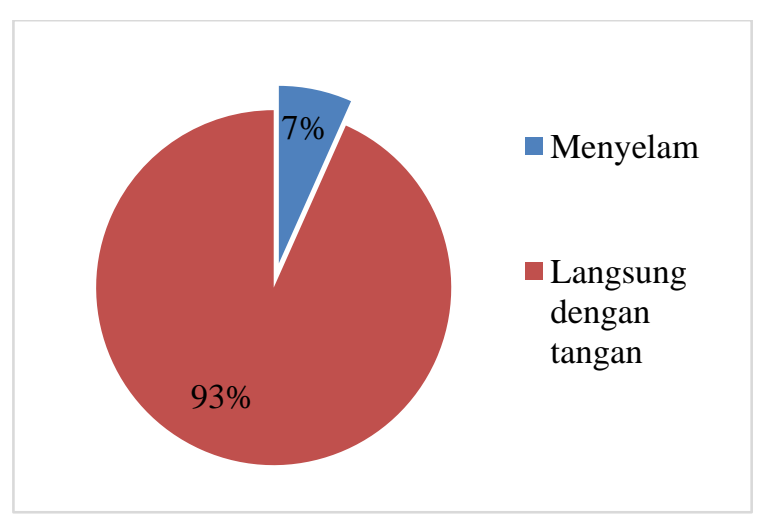

(b)

Gambar 5. (a) Alasan penangkapan dan (b) Cara penangkapan kerang bulu di Perairan Sebong Pereh 
Gambar 5. menujukkan bahwa sebesar 63\% nelayan melakukan penangkapan kerang bulu karena harga yang cukup tinggi dan dapat menambah penghasilan sehari-hari. Sedangkan sebesar 37\% hanya menjadikannya sebagai makanan untuk konsumsi. Masyarakat yang menangkap kerang bulu hanya untuk kebutuhan makanan sehari-hari menjadikan pekerjaan tersebut sebagai pekerjaan sampingan, sedangkan masyarakat yang menangkap kerang bulu menjadi pekerjaan pokok, menangkap kerang bulu karena harga yang tinggi.

Kerang memiliki potensi dan gizi yang tinggi dan dapat memenuhi kebutuhan konsumsi masyarakat untuk makanan sehari-hari. Kerang bulu memiliki kandungan gizi, protein dan karbohidrat yang cukup tinggi, itu sebabnya kerang bulu banyak dikonsumsi oleh masyarakat. Menurut Arnanda et al. (2005), hasil penelitiannya menunjukkan bahwa kadar protein pada kerang bulu A. inflata berkisar antara 6,79 \% - $1192 \%$; kadar lemak berkisar antara 4,2 \% - 6,16 $\%$, dan kadar karbohidrat berkisar antara 2,3\% - 4,35 \%. Sedangkan kadar air terendah terdapat dalam kerang bulu berukuran 20,0 - 30,0 mm sebesar 77,55 \% dan kadar air terbanyak terdapat dalam kerang berukuran 50,10 - 60,0 mm sebesar $82,64 \%$; dan kadar abu berkisar antara 1,27 \% - 2,08\%.

Penangkapan kerang bulu umumnya masih dilakukan dengan cara tradisional yakni menggunakan tangan. Sebesar 93\% masyarakat melakukan penangkapan kerang bulu secara langsung dengan tangan, dengan melihat bentuk bukaan cangkang kerang bulu yang timbul ke permukaan substrat. Sedangkan hanya sebesar $7 \%$ nelayan kerang bulu melakukan penangkapan dengan cara menyelam menggunakan snorkel sederhana. Namun penyelaman hanya dilakukan pada saat air surut tidak terlalu jauh, akan tetapi pengambilan kerang bulu masing menggunakan tangan (tidak menggunakan alat tangkap).

Penangkapan kerang bulu di perairan Desa Sebong Pereh yang dilakukan masih manual dengan menggunakan tangan dan tidak menggunakan alat tangkap. Kondisi penangkapan kerang bulu seperti ini tentunya sangat baik dibandingkan menggunakan alat tangkap. Alat tangkap kerang bulu disebut dengan "garuk" yang saat ini telah banyak digunakan di beberapa lokasi di Indonesia. Namun efeknya kurang baik bagi kelangsungan ekosistem sekitarnya. Diketahui bahwa kerang bulu hidup pada area padang lamun hingga batas tubir terumbu karang, jika penangkapan dilakukan dengan alat garuk tentunya akan merusak ekosistem terebut. Seperti penelitian Wiyono (2009), bahwa target dari alat tangkap garuk diantaranya: kerang hijau (Perna viridis), kerang mencos (Anadara indica), dan kerang bulu (Anadara antiquata.). Dampak buruk dari penggunaan alat ini yakni kerusakan pada ekosistem dasar disektarnya terutama lamun dan terumbu karang.

Selanjutnya musim penangkapan dan waktu penangkapan kerang bulu di Desa Sebong Pereh disajikan secara lengkap seperti pada Gambar 6.

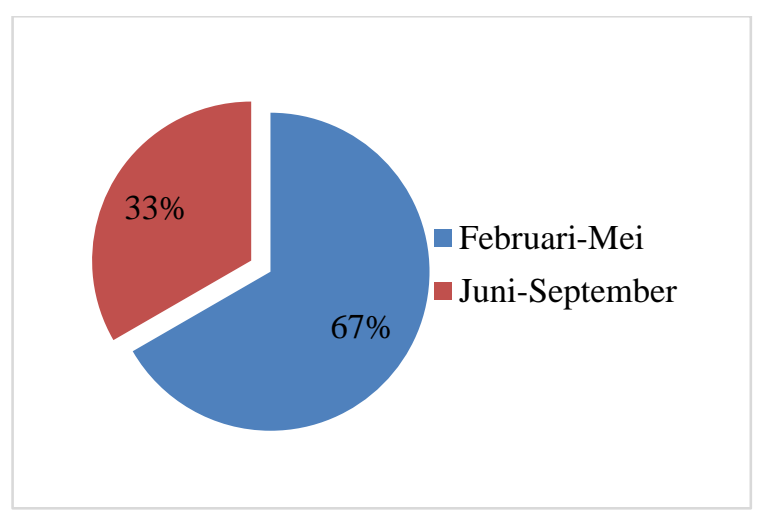

(a)

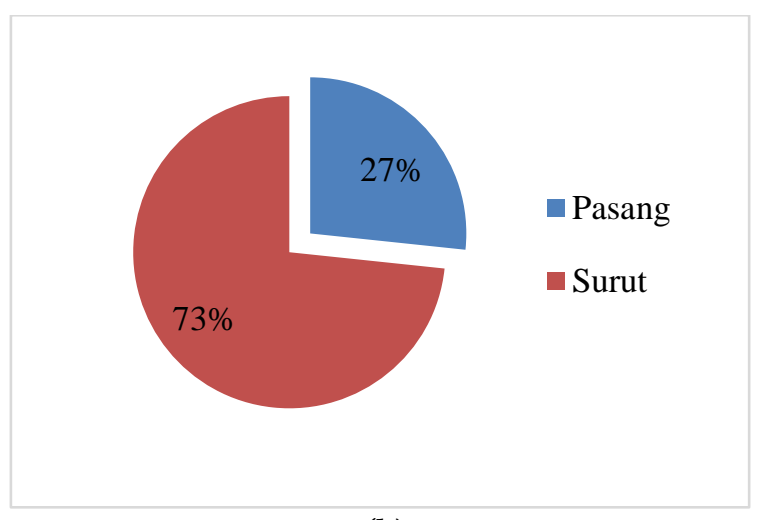

(b)

Gambar 6. (a) Musim penangkapan dan (b) Waktu penangkapan kerang bulu di Perairan Sebong Pereh

Berdasarkan hasil wawancara, masyarakat umumnya melakukan penangkapan pada saat musim teduh yakni antara bulan Februari-Mei. Sedangkan sebesar $33 \%$ masyarakat juga melakukan penangkapan kerang bulu pada musim peralihan antara bulan Juni-September. Pada saat musim tenang, nelayan lebih intensif melakukan penangkapan kerang bulu karena kerang bulu lebih mudah dijumpai dan kecerahan air lebih baik dibandingkan dengan musim peralihan. Menurut penuturan masyarakat, pada musim tenang, umumnya kerang bulu lebih mudah dikenali dibandingkan dengan musim angin kuat. Pada saat musim angin kuat, kerang bulu akan sulit dikenali karena tertutupi oleh pengadukan sedimen yang diaduk oleh kuatnya arus air. Masyarakat umumnya melakukan penangkapan kerang bulu pada saat surut di pagi dibandingkan pada saat air laut pasang. Untuk lama waktu penangkapan dan ukuran kerang bulu yang ditangkap disajikan pada Gambar 7.

Selanjutnya, dari total responden sebesar 80\% masyarakat melakukan penangkapan kerang bulu dengan lama waktu antara 2-4 jam, sedangkan sisanya sebesar 20\% melakukan penangkapan antara 1-2 jam. Lama waktu penangkapan kerang bulu umumnya dipengaruhi oleh interval waktu sesuai dengan lamanya kondisi surut air. Jika surut dengan interval yang panjang, penagkapan kerang bulu akan lebih lama dibandingkan pada saat surut dengan interval waktu yang pendek. 


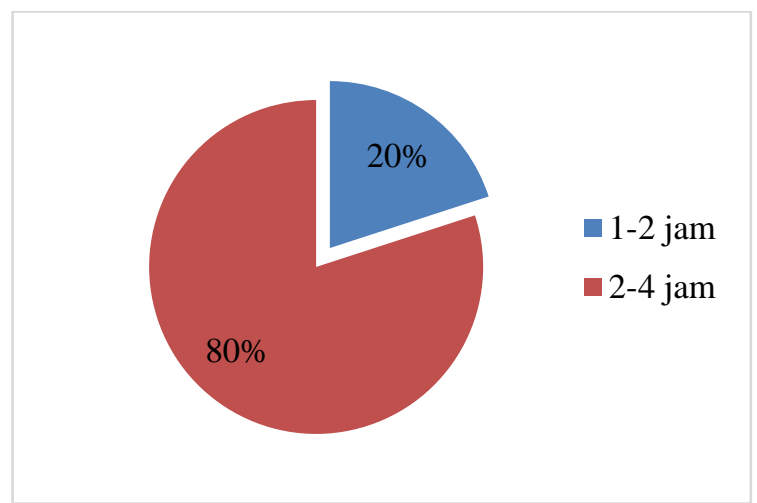

(a)

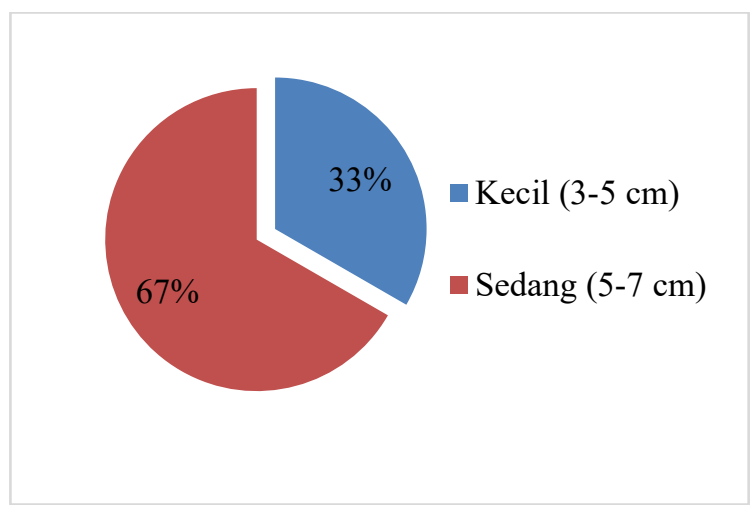

(b)

Gambar 7. (a) Lama waktu penangkapan dan (b) Ukuran yang ditangkap kerang bulu di Perairan Sebong Pereh

Ukuran kerang bulu yang ditangkap oleh nelayan beragam ukurannya mulai dari yang berukuran kecil $( \pm 3-5 \mathrm{~cm})$, sedang $(5-7 \mathrm{~cm})$, dan besar $(>7 \mathrm{~cm})$. Pembagian ukuran kerang ini dibagi berdasarkan hasil penelitian Triana (2016) yang mengatakan bahwa ukuran kerang/bivalvia yang ditangkap nelayan di perairan Pulau Bintan berkisar antara 3-7 cm. Dari hasil penelitian, sebesar 67\% masyarakat Desa Sebong Pereh menangkap kerang bulu berukuran sedang, sedangkan sisanya 33\% melakukan penangkapan dengan ukuran kerang bulu yang kecil. Berdasarkan penuturan masyarakat, kerang bulu yang berukuran besar sudah cukup sulit diperoleh sehingga ukuran yang relatif kecil juga ditangkap, jika ini terus berlanjut akan membahayakan populasi kerang bulu di Perairan Desa Sebong Pereh.

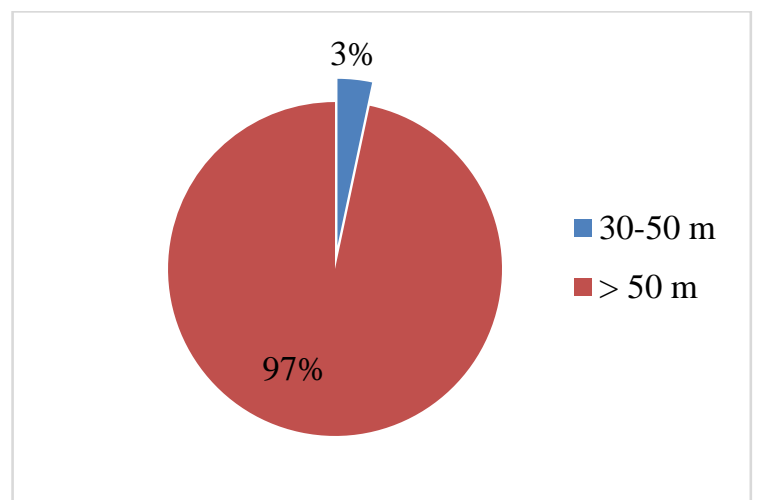

(a)

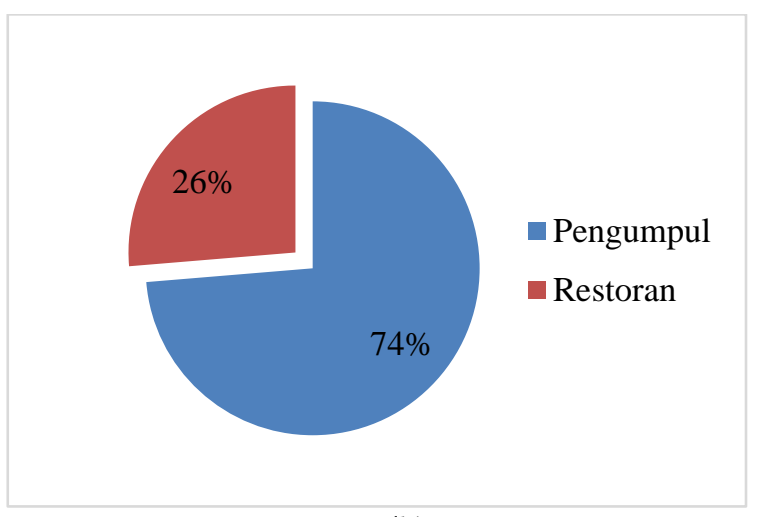

(b)

Gambar 8. (a) Jarak penangkapan, dan (b) Distribusi penjualan kerang bulu di Perairan Sebong Pereh

Gambar 8. (a) menunjukkan bahwa jarak tangkapan kerang bulu dari bibir pantai Sebong Pereh yang dilakukan oleh masyarakat yakni > 50 meter. Penangkapan kerang bulu dilakukan pada kawasan ekosistem lamun yang jaraknya cukup jauh dari bibir pantai sekitar 200-400 meter karena tipikal perairan Desa Sebong Pereh yang landau dengan batas tubir yang cukup jauh. Seperti pernyataan Akhrianti et al. (2014), bivalvia tersebar secara luas di seluruh pesisir perairan Indonesia khususnya di berbagai ekosistem perairan dangkal seperti ekosistem lamun, alga, dan terumbu karang. Lebih lanjut Simuhu et al. (2016), kerang bulu merupakan salah satu jenis dari filum moluska. Kerang bulu yaitu kerang yang hidup pada ekosistem lamun dan membenamkan diri pada substrat.

Gambar 8. (b) menunjukkan bahwa distribusi kerang bulu yang ditangkap oleh masyarakat Desa Sebong Pereh sebesar 74\% umumnya di salurkan ke pengumpul, dan sisanya 26\% disalurkan ke restaurant sekitar. Alasan nelayan kerang bulu menjual hasil tangkapan ke pengumpul yakni karena pengumpul secara langsung mendatangi masyarakat sehingga lebih mudah untuk transaksi. Dibandingkan dengan melakukan penjualan ke restauran yang harus diantarkan ke restaurant tersebut. Ternyata selain dari kerang bulu A. antiquata yang juga dijual oleh masyarakat Sebong Pereh ialah kerang kijing Gafrarium pectinatum, kerang remis Mactra sp.

Secara keseluruhan, nelayan kerang bulu keseluruhan menjual hasil tangkapannya ke konsumen ataupun pengumpul. Hasil ini berkaitan dengan nilai manfaat langsung atau Direct Use Value (DUV) penangkapan kerang bulu di perairan Sebong Pereh berkisar antara Rp. 79.500,- perminggu hingga Rp. 89.500,- perminggu dengan rata-rata nilai manfaat langsung sebesar Rp. 84.958,- perminggu. Dengan demikian, pendapatan nelayan kerang bulu berkisar antara Rp. 318.000,- perbulan hingga Rp. 358.000,- perbulan dengan rata-rata Rp. 339.833,- perbulan (Rp. 4.078.000,- pertahun). 
Kondisi ini menggambarkan bahwa masyarakat umumnya melakukan penjualan kerang bulu karena dapat menambah penghasilannya.

Kerang bulu sangat memungkinkan untuk dijadikan sebagai bahan makanan karena kandungan gizi yang tinggi. Menurut Srimariana et al. (2015), kerang merupakan salah satu jenis makanan hasil laut yang digemari masyarakat karena rasanya yang lezat dan juga memiliki kandungan gizi tinggi. Kerang dijadikan sebagai salah satu sumber makanan alternatif selain ikan, terutama pada saat musim ombak dimana ikan sulit didapat, kerang diambil pada saat air laut surut.

\section{SIMPULAN}

Kelimpahan kerang bulu rata-rata sebesar 5667 ind/ha, kelimpahan Kerang Bulu A. antiquata di Perairan Desa Sebong Pereh tergolong kelimpahan yang sedang. Total hasil tangkapan (catch) yang diperoleh berkisar antara $477-537 \mathrm{~kg} / \mathrm{minggu}$ dengan hasil tangkapan rata-rata sebesar $509,75 \mathrm{~kg} / \mathrm{minggu}$. Upaya penangkapannya fluktuatif antara 44-59 trip/minggu dengan rata-rata upaya sebesar 51 trip/minggu. Pendapatan nelayan kerang bulu berkisar antara Rp. 318.000,- perbulan hingga Rp. 358.000,- perbulan dengan rata-rata Rp. 339.833,-- perbulan (Rp. 4.078.000,- pertahun).

\section{UCAPAN TERIMA KASIH}

Pada kesempatan ini Penulis menyampaikan terima kasih kepada Ibu Fitria Ulfah, SP, MM selaku Pembimbing Utama dan Bapak Tri Apriadi, S.Pi, M.Si selaku Pembimbing Pendamping yang telah bersedia memberikan arahan dan bimbingan pada penulis dalam penyusunan penelitian ini.

\section{REFERENSI}

Agustina, L. (2014). Struktur Komunitas dan Valuasi Ekonomi Ekosistem Padang lamun di Kawasan Konservasi Laut Daerah Desa Berakit Bintan. Universitas Maritim Raja Ali Haji.

Akhirianti, I., Bengen. D.G., \& Setyobudiandi, I. (2014). Distribusi Spasial dan Preferensi Habitat Bivalvia di Pesisir Perairan Kecamatan Simpang Pesak Kabupaten Belitung Timur. Ilmu dan Teknologi Kelautan Tropis, 6(1): 171-185.

Arnanda, A.D., Ambariyanto, \& Ridlo, A. (2005). Fluktuasi Kandungan Proksimat Kerang Bulu (Anadara inflata reeve) di Perairan Pantai Semarang. Ilmu Kelautan, 10(2): 78-84.

Dayanti, F., Bahtiar, \& Ishak. E. (2017). Kepadatan dan Distribusi Kerang Bulu (Anadara antiquata L, 1758) di perairan Wangi-wangi Selatan Desa Numana Kabupaten Wakatobi. Manajemen Sumber Daya Perairan, 2(2): 113-122.

Ernawati, E., Aprianto, R., \& Musfiroh, I. (2015). Analisis Timbal dalam Kerang Hijau, Kerang Bulu, dan Sedimen di Teluk Jakarta. IJPST, 2(3): 105-111.

Keputusan Menteri Negara Lingkungan Hidup Nomor 51 Tahun 2004 tentang Baku Mutu untuk Biota laut.

Kharisma, D., Adhi, C., \& Azizah, T.N. (2012). Kajian Ekologis Bivalvia di Perairan Semarang bagian Timur pada Bulan Maret-April 2012. Marine Research, 1(2): 216-225.

Nurdiani, N. (2014). Teknik Sampling Snowball dalam Penelitian Lapangan. ComTech, 5(2): 1110-1118.

Prasojo, S.A., Irwani, \& Suryono, C.A. (2012). Distribusi dan Kelas Ukuran Panjang Kerang Darah (Anadara granosa) di Perairan Pesisir Kecamatan Genuk, Kota Semarang. Marine Research, 1(1): 137-145.

Putri, A.M.S., Suryanti, \& Widyorini., N. (2016). The Relation of Sediment Texture to Organic Matter and Macrozoobenthos Abundance in the Estuarine of Banjir Kanal Timur River. Fisheries Science and Technology, 12(1): 75-80.

Riniatsih, I., \& Widianingsih. (2007). Kelimpahan dan Pola Sebaran Kerang-kerangan (Bivalva) di Ekosistem Padang Lamun, Perairan Jepara. Ilmu Kelautan, 12(1): 53-58.

Riniatsih, I., \& Kushartono, E.W. (2009). Substrat Dasar dan Parameter Oseanografi Sebagai Penentu Keberadaan Gastropoda dan Bivalvia di Pantai Sluke Kabupaten Rembang. Ilmu Kelautan, 14(1): 50-59.

Rochmady \& Susiana. (2014). Pendugaan Stok Ikan Kerapu (Grouper) di Perairan Selat Makassar, Sulawesi Selatan Periode Tahun 1999-2007. Agrikan: Jurnal Agribinis dan Perikanan, 7(2): 60-67.

Satrioajie, W.N. (2012). Potensi dan Aspek Biologi Kerang Bulu Anadara pilula (Reeve, 1843) di Sekitar Perairan Pantai Kota Tegal. Oseanologi dan Limnologi di Indonesia, 38(2 : 189-202.

Setiawan, A., Bahtiar., \& Nurgayah, W. (2016). Pola Pertumbuhan dan Rasio Bobot daging Kerang Bulu (Andara antiquata) di Perairan Bungkutoko Kota Kendari. Manajemen Sumber Daya Perairan, 1(2): 115-129.

Simuhu, T., Bahtiar, \& Oetama, D. (2016). Eksploitasi Kerang Bulu (Anadara antiquata) di Perairan Pantai Bungkutoko Sulawesi Tenggara. Manejemen Sumber Daya Perairan, 1(3): 261-274.

Sparre, P., \& Venema, S.C. (1999). Introduksi Pengkajian Stok Ikan Tropis. Pusat Penelitian dan Pengembangan Perikanan. Jakarta. Hal. 303-310.

Susiana \& Rochmady. (2018). Pendugaan stok cumi-cumi Loligo sp. di Perairan Kabupaten Pangkajene dan Kepulauan, Sulawesi Selatan, Indonesia. Jurnal Pengelolaan Perairan, 1(1): 14-30.

Susilo, E., Islamy, F., Saputra, A.J., Hidayat, J.J., Zaky, A.R, \& Suniada, K.I. (2015). Pengaruh Dinamika Oseanografi terhadap Hasil Tangkapan Ikan Pelagis PPN Kejawanan dari Data Satelit Oseanografi. Senmas Teknologi Penangkapan Ikan, 299-304.

Supriadi, I.H. (2002). Sekilas Valuasi Ekonomi Sumberdaya Laut. Oseana, 27(2): 11-19.

Srimariana, E.S, Silaban, B., \& Lokollo, E. (2015). Potensi kerang manis (Gafrarium tumidum) di pesisir Pantai Negeri Laha, Teluk Ambon sebagai sumber mineral. Biodiversity Indonesia. Pros Sem Nas Masy Biodiv Indon, 1(4): 843-847.

Triana, D. (2016). Analisis Sumberdaya Bivalvia pada Ekosistem Padang Lamun dan Pemanfaatannya di Desa Pengudang Kabupaten Bintan. Universitas Maritim Raja Ali Haji.

Wiyono, E.S. (2009). Species Selectivity of Garuk in Cirebon. Bumi Lestari, 9(1): 61-65. 